\title{
TINJAUAN YURIDIS IMPLEMENTASI CONSERVATOIR BESLAG (SITA JAMINAN) DALAM PUTUSAN NOMOR 2/PDT.G/2018/PN MJL
}

\author{
Oleh : Wiwin Widiyaningsih ${ }^{1}$ \\ Sandyana Abdurochim
}

\begin{abstract}
ABSTRAK
Penelitian ini mengambil judul "Tinjauan Yuridis Implementasi Conservatoir Beslag (Sita Jaminan) Dalam Putusan Nomor 2/Pdt.G/2018/PN Mjl". Penelitian ini dilakukan dengan tujuan untuk mengetahui pertimbangan hukum Hakim Pengadilan Negeri Majalengka dalam mengkualifisir permohonan sita jaminan, sehingga menyatakan sah dan berharga dalam Putusan Nomor 2/Pdt.G/2018/PN Mjl.

Penelitian ini menggunakan metode pendekatan hukum secara normatif, dengan spesifikasi penelitian deskriptif. Dalam penelitian ini sumber data yang digunakan adalah data sekunder berupa Putusan Perkara Pengadilan Negeri Majalengka Nomor 2/Pdt.G/2018/PN Mjl, undang-undang dan buku-buku literatur yang berkaitan dengan permasalahan penelitian. Data yang diperoleh disajikan secara sistematis dan terperinci, dan analisis data dilakukan secara normatif.

Hasil yang dapat diambil dari penelitian ini adalah berdasarkan fakta-fakta di persidangan, serta bukti-bukti dan keterangan para saksi yang diajukan oleh kedua belah pihak, maka Koperasi Dwi Fani dinyatakan telah melakukan perbuatan melawan hukum yakni menggelapkan uang milik para penggugat sebagai nasabah koperasi Dwi Fani. Tergugat I sebagai ketua, Tergugat II sebagai sekertaris, Tergugat III dan IV sebagai bendahara dan Tergugat V sebagai pengawas dari Koperasi Dwi Fani yang sah dan bertanggung jawab untuk mengembalikan uang milik Para penggugat sebagai nasabah sebesar Rp.2.391.494.600 (dua miliar tiga ratus sembilan puluh satu juta empat ratus sembilan puluh empat ribu enam ratus rupiah) secara kontan. Inilah yang dijadikan hakim sehingga menyatakan sah dan berharga Conservatoir beslag (Sita jaminan) yang telah dilaksanakan oleh Jurusita/ Jurusita Pengganti Pengadilan Negeri Majalengka Kelas II berdasarkan Berita Acara Penyitaan Nomor 2/Pen.Pdt.G/2018/PN.Mjl tanggal 5 Juni 2018, terhadap objek sengketa.
\end{abstract}

Kata kunci : Tinjauan Yuridis, Implementasi, Conservatoir Beslag

\footnotetext{
${ }^{1}$ Dosen Fakultas Hukum Universitas Majalengka
} 


\section{A. Latar Belakang Penelitian}

Hukum acara perdata adalah peraturan hukum yang mengatur bagaimana caranya menjamin ditaatinya hukum perdata materiil dengan perantara hakim, jadi hukum acara perdata dapat dikatakan peraturan hukum yang menentukan bagaimana caranya menjamin pelaksanaan hukum perdata materiil. Konkritnya dapat dikatakan, bahwa hukum acara perdata mengatur tentang bagaimana caranya mengajukan tuntuan hak, memeriksa serta memutusnya dan pelaksanaan dari putusannya tersebut.

Tuntutan hak adalah tindakan yang bertujuan memperoleh perlindungan hak yang diberikan oleh pengadilan untuk mencegah "eigenrichting" (main hakim sendiri). Tindakan menghakimi sendiri merupakan tindakan untuk melaksanakan hak menurut kehendaknya sendiri yang bersifat sewenang-wenang, tanpa persetujuan dari pihak lain yang berkepentingan, sehingga akan menimbulkan kerugian. Tindakan menghakimi sendiri ini tidak dibenarkan dalam hal kita hendak memperjuangkan atau melaksanakan hak kita. $^{2}$

Orang yang mengajukan tuntutan hak memerlukan atau berkepentingan akan perlindungan hukum, maka diajukanlah tuntutan tersebut ke pengadilan. Seseorang yang mengajukan gugatan kepada pengadilan negeri, bukan saja mengharapkan agar memperoleh putusan yang menguntungkan baginya, tetapi juga mengharapkan putusan tersebut akhirnya dapat

2 Sudikno Mertokusumo, Hukum Acara Perdata Indonesia, Liberty, Yogyakarta,2006,hlm.2. dilaksanakan dan gugatan yang telah dikabulkan tersebut tidak illusionir (hampa).

Undang-undang menyediakan suatu upaya agar gugatan dari penggugat tersebut tidak illusionir (hampa) di kemudian hari, apabila gugatannya nanti dikabulkan, yaitu dengan sita jaminan.

Pasal 227 ayat (1) HIR (Pasal 261 ayat (1) Rbg) menyatakan: "Jika ada persangkaan yang beralasan, bahwa seseorang yang berutang, selagi belum dijatuhkan keputusan atasnya atau selagi putusan yang mengalahkannya belum dapat dijalankan, mencari akal akan menggelapkan atau membawa barangnya baik yang tidak tetap maupun yang tetap dengan maksud akan menjauhkan barang itu dari penagih utang, maka atas surat permintaan orang yang berkepentingan Ketua Pengadilan Negeri dapat memberi perintah supaya disita barang itu untuk menjaga hak orang yang memasukkan permintaan itu, dan kepada peminta harus diberitahukan akan menghadap persidangan pengadilan negeri yang pertama sesudah itu untuk memajukan dan menguatkan gugatannya."

Sita jaminan mengandung arti bahwa untuk menjamin pelaksanaan suatu putusan di kemudian hari, barang-barang milik tergugat baik yang bergerak maupun yang tidak bergerak selama proses perkara berlangsung terlebih dahulu disita. Barang-barang yang sudah disita tidak dapat dialihkan, diperjualbelikan atau dipindahtangankan kepada orang lain,

3 Ropaun Rambe, Hukum Acara Perdata Lengkap, Sinar Grafika, Jakarta, 2002, hlm. 270. 
hal ini adalah menyangkut sita conservatoir (conservatoir beslag). ${ }^{4}$

Pengadilan Negeri Majalengka

telah menjatuhkan putusan atas perkara nomor 2/Pdt.G/2018/PN Mj1. pada tanggal 27 Agustus 2018 putusan tersebut dijatuhkan atas gugatan yang dilayangkan kepada Pengadilan Negeri Majalengka atas alas gugat yaitu 12 (dua belas) bidang tanah dan bangunan yang terletak di Kecamatan Jatitujuh Kabupaten Majalengka.

Penggugat dalam perkara ini yaitu :

1. Ahmad

Sholehudin,

berkedudukan di Blok Senin, RT.14, RW. 07, Desa Jatitujuh, Kecamatan Jatitujuh,Kabupaten Majalengka sebagai Penggugat I;

2. Ita Casmita, berkedudukan di Blok Senin, RT.14, RW. 07, Desa Jatitujuh, Kecamatan Jatitujuh, Kabupaten Majalengka sebagai Penggugat II;

3. Masripah, berkedudukan di Blok Senin, RT.14,RW.07, Desa Jatitujuh, Kecamatan Jatitujuh, Kabupaten Majalengka sebagai Penggugat III;

4. Sumiyati, berkedudukan di Blok Jum'at, RT. 01， RW. 01， Desa Jatitujuh, Kecamatan Jatitujuh, Kabupaten Majalengka sebagai Penggugat IV;

5. Carto, berkedudukan di Blok Kemped, RT.11, RW.04, Desa Ranajawat, Kecamatan Tukdana, Kabupaten Indramayu sebagai Penggugat V;

6. H. Iksan Kamil, berkedudukan di Blok Manis, RT.06, RW. 03, Desa

4 Retnowulan Sutantio dan Iskandar Oeripkartawinata, Hukum Acara Perdata Dalam Teori dan Praktek, Mandar Maju, Bandung, 2002, hlm. 99.
Randegan Kulon, Kecamatan Jatitujuh, Kabupaten Majalengka sebagai Penggugat VI;

7. Heni Kurnia Ningsih, berkedudukan di Blok Panjalin, RT. 09, RW. 03, Desa Panyingkiran, Kecamatan Jatitujuh, Kabupaten Majalengka sebagai Penggugat VII;

8. Enjo Ahmad Suhrjo, berkedudukan di Blok Minggu, RT.09, RW. 05, Desa Jatitujuh, Kecamatan Jatitujuh, Kabupaten Majalengka sebagai Penggugat VIII;

9. Saepullah, berkedudukan di Blok Minggu, RT. 09, RW. 05, Desa Jatitujuh, Kecamatan Jatitujuh, Kabupaten Majalengka sebagai Penggugat IX;

10. Taufik Ismail, berkedudukan di Blok Senin, RT.13, RW.7, Desa Jatitujuh, Kecamatan Jatitujuh, Kabupaten Majalengka sebagai Penggugat $\mathrm{X}$;

11. Hj. Badriah, berkedudukan di Blok Minggu, RT. 10, RW. 05, Desa Jatitujuh, Kecamatan Jatitujuh, Kabupaten Majalengka sebagai Penggugat XI;

Para Penggugat dalam hal ini memberikan kuasa kepada DR. J. Samsudin Saputra, S.H., M.H., DR. H. Achamad Santoso, S.H,. M.H., M. Sayafrudin, S.H dan Mochamad Danu Ismanto, S.H, Advokat/ Pengacara, yang berkantor pada kantor Advokat dan Pengacara Dr. J. Samsudin Saputra, S.H., M.H and Partner Jl Perjuangan Kav Cimanuk B9 (sebelah SMA 5) Cirebon berdasarkan Surat Kuasa Khusus tanggal 18 Desember 2017 mengajukan gugatan kepada pihak tergugat secara tertulis ke Pengadilan Negeri Majalengka. Dasar gugatan mengenai pelunasan seluruh 
uang nasabah Koperasi Dwi Fani yang belum keluar karena perbuatan para tergugat secara tanggung renteng sampai tahun 2018 ini, maka dengan ini Para Penggugat akan mengajukan sita jaminan.

Conservatoir beslag yang dimohonkan oleh penggugat dikabulkan oleh Pengadilan Negeri Majalengka dan dilaksanakan oleh Jurusita/ Jurusita Pengganti Pengadilan Negeri Majalengka Kelas II berdasarkan Berita Acara Penyitaan Nomor 2/Pen.Pdt.G/2018/PN.Mjl tanggal 5 Juni 2018 yang menyatakan bahwa conservatoir beslag tersebut sah dan berharga.

\section{B. Rumusan Masalah}

Berdasarkan latar belakang di atas, maka rumusan masalah dalam penelitian ini adalah sebagai berikut :

1. Bagaimana fungsi dan kedudukan daripada sita jaminan dalam perkara perdata?

2. Bagaimana pertimbangan hukum dari Hakim Pengadilan Negeri Majalengka dalam mengkualifisir permohonan sita jaminan, sehingga menyatakan sah dan berharga dalam putusan nomor 2/Pdt.G/2018/ PN.Mj1?

\section{Tujuan Penelitian}

Dari rumusan permasalahan yang telah diuraikan di atas, maka tujuan yang hendak dicapai dalam penelitian ini yaitu :

1. Mengetahui, meneliti dan mengkaji fungsi dan kedudukan daripada sita jaminan dalam perkara perdata.

2. Mengetahui pertimbangan hukum dari Hakim Pengadilan Negeri
Majalengka dalam mengkualifisir permohonan sita jaminan, sehingga menyatakan sah dan berharga dalam putusan nomor 2/Pdt.G/2018/PN.Mjl.

\section{Kerangka Pemikiran}

Kerangka Pemikiran merupakan model konseptual tentang bagaimana teori berhubungan dengan berbagai faktor yang telah diidentifikasi sebagai hal yang penting, jadi dengan demikian maka kerangka pemikiran adalah sebuah pemahaman yang melandasi pemahaman pemahaman lainnya, sebuah pemahaman yang paling mendasar dan menjadi pondasi bagi setiap pemikiran atau suatu bentuk proses dari keseluruhan dari penelitian yang akan dilakukan dan untuk mempermudah penulis dalam melakukan penelitian, maka penulis mengaitkan dengan beberapa teori, diantaranya :

\section{Teori Negara Hukum}

Negara Hukum atau dikenal dengan istilah rechtsstaat maupun the rule of law, walaupun keduanya berasal dari 2 (dua) tradisi yang berbeda. Paham rechtsstaat pada dasarnya bertumpu pada sistem hukum Eropa Kontinental. Paham rechtsstaat dikembangkan oleh ahliahli hukum Eropa Kontinental seperti Immanuel Kant dan Friederich Julius Stahl, bahwa ide tentang rechtsstaat mulai populer pada abad ke XVII sebagai akibat dari situasi politik Eropa yang didominir oleh absolutisme Raja, sedangkan paham the rule of law bertumpu pada sistem hukum anglo saxon atau common law system. Paham the rule of law mulai dikenal setelah Albert Venn Dicey pada tahun 1885 menerbitkan 
bukunya Introduction to Study of the Law of the Constitution, Negara hukum bersandar pada keyakinan bahwa kekuasaan negara harus dijalankan atas dasar hukum yang adil dan baik. Ada dua unsur dalam negara hukum, yaitu pertama: hubungan antara yang memerintah dan yang diperintah tidak berdasarkan kekuasaan melainkan berdasarkan suatu norma objektif, yang juga mengikat pihak yang memerintah; kedua: norma objektif itu harus memenuhi syarat bahwa tidak hanya secara formal, melainkan dapat dipertahankan berhadapan dengan idea hukum.

Jadi Pengertian Negara hukum adalah Negara yang didalamnya menjalankan suatu tindakan yang didasarkan kepada aturan-aturan hukum yang sudah ada. Dengan demikian, tugas Negara ialah menjalankan kesadaran hukum didalam suatu bentuk peraturanperaturan hukum yang berlaku serta juga harus ditaati oleh tiap-tiap warga negaranya. ${ }^{5}$

\section{Teori Koperasi}

Koperasi merupakan badan usaha yang anggotanya memiliki prinsip yang berlandaskan pada perekonomian rakyat. Pada pernyataan yang lain dijelaskan bahwa, koperasi ialah suatu perkumpulan dari orang-orang yang atas dasar persamaan derajat sebagai manusia, dengan tidak memandang haluan agama dan politik secara sukarela masuk, untuk sekedar memenuhi kebutuhan bersama yang

dari

5 Wikipedia, Negara Hukum, diakses

https://id.wikipedia.org/wiki/Negara_hukum, pada tanggal 17 Nopember 2018 bersifat kebendaan atas tanggungan bersama.

Penjelasan dari kata-kata yang terdapat dalam definsi tersebut, selanjutnya dapat diterangkan sebagai berikut; kumpulan orang-orang, menjelaskan bahwa sebuah koperasi yang diutamakan bukanlah modal atau uang, akan tetapi orang-orang yang menjadi anggota dan masingmasing anggota tersebut memiliki hak yang sama. Persamaan derajat, menjelaskan bahwa dalam hal keanggotaan, koperasi tidak membedakan antara pria dan wanita, pesuruh atau kepala bagian ataupun direktur. Masing-masing dari mereka memiliki hak suara yang sama. Tidak memandang haluan agama dan politik, menjelaskan bahwa koperasi tidak dibawa kedalam salah satu aliran agama dan politik. Sukarela,maksudnya keanggota koperasi tidak boleh dipaksakan, dan seseorang itu bebas keluar masuk menjadi anggota. Tanggungan Bersama,sesama anggota koperasi memiliki rasa tanggung jawab yang sama atas kewajiban mereka terhadap koperasi. Misalnya, jika suatu hari koperasi mengalami kerugian, maka hal tersebut manjadi tanggungan bersama. ${ }^{6}$

Koperasi merupakan kumpulan orang yang memiliki tujuan dalam memenuhi kebutuhan ekonomi melalui badan usaha yang dijalankan anggota sebagai pemilik sekaligus pengguna jasa koperasi. Sebagai pemilik usaha anggota koperasi harus berusaha menyediakan kebutuhan yang diperlukan oleh

6 Hendrojogi. Koperasi: Asas-asas, Teori dan Praktik. Edisi 4. Jakarta. Raja Grafindo Persada. 2007, hlm 25 
sesama anggotanya. Meskipun untuk melakukan transaksi dengan koperasinya tetap menggunakan uang, tetapi dengan menjadi pengguna bersama kebutuhan pengeluaran uang dapat ditekankan dengan serendah mungkin (minimized). Karena pada dasarnya koperasi memperoleh keuntungan dari hasil pembelian atau penjualan yang dilakukan secara efisien, bukan perhitungan untung rugi yang digunakan koperasi terhadap anggotanya, akan tetapi sisa hasil usaha dari adanya efisiensi tersebut. ${ }^{7}$

\section{Teori Hukum Acara Perdata}

Menurut Wirjono Prodjodikoro yang disadur dalam buku Abdulkadir Muhammad, hukum acara perdata itu sebagai rangkaian peraturanperaturan yang memuat cara bagaimana orang harus bertindak terhadap dan dimuka pengadilan dan cara bagaimana pengadilan itu harus bertindak satu sama lain untuk melaksanakan berjalannya peraturan-peraturan hukum perdata. ${ }^{8}$

Hukum acara perdata dapat disimpulkan sebagai peraturan hukum yang mengatur bagaimana cara menjamin ditaatinya hukum perdata materiil dengan perantara hakim, dengan kata lain hukum acara perdata adalah peraturan hukum yang menentukan bagaimana caranya menjamin pelaksanaan hukum perdata materiil. Tuntutan yang diajukan oleh salah satu pihak adalah tidak lain tindakan yang bertujuan

7 Burhanuddin Susamto, , Koperasi Syariah dan Pengaturannya di Indonesia, Malang, UIN - Maliki Press, 2012, hlm 50

Abdulkadir Muhammad, Hukum Acara Perdata Indonesia, Bandung, Alumni, 1990, hlm.17 memperoleh perlindungan hukum yang diperoleh melalui pengadilan untuk mencegah tindakan main hakim sendiri atau "eigenrichting".9

\section{Teori Gugatan}

Tindakan mempertahankan hak menurut hukum itu disebut gugatan, yakni suatu upaya atau tindakan untuk menuntut hak, atau memaksa pihak lain untuk melaksanakan tugas atau kewajibannya, guna memulihkan kerugian yang diderita oleh penggugat melalui putusan pengadilan. Surat gugatan adalah salah satu dari permohonan yang diajukan kepada Ketua Pengadilan Negeri yang berwenang. Isinya memuat tanggal surat gugatan, nama dan alamat penggugat dan tergugat atau identitas, posita gugatan, petitum gugatan atau hal-hal yang dimintakan oleh penggugat untuk dikabulkan pengadilan, dimaterai secukupnya dan ditanda tangani. Orang yang buta huruf, maka gugatannya akan dibuat atau disuruh buatkan oleh Ketua Pengadilan Negeri sesuai ketentuan Pasal 388 HIR (Herzeine Inlandsch Reglement).

\section{Teori Penyitaan}

Penyitaan berasal dari terminologi beslag (Belanda), dan istilah Indonesia beslah tetapi istilah bakunya ialah sita atau penyitaan.

Pengertian yang terkandung di dalamnya ialah :

a. Tindakan menempatkan harta kekayaan tergugat secara paksa berada ke dalam keadaan penjagaan (to take intocustody the property of a defendant),

b. Tindakan paksa penjagaan

\footnotetext{
${ }^{9}$ Sudikno Mertokusumo, op.cit., hlm.2
} 
(custody) itu dilakukan secara resmi (official) berdasarkan perintah pengadilan atau hakim,

c. Barang yang ditempatkan dalam penjagaan tersebut, berupa barang yang disengketakan, tetapi boleh juga barang yang akan dijadikan sebagai alat pembayaran atas pelunasan utang debitur atau tergugat, dengan jalan menjual lelang (executorial verkoop) barang yang disita tersebut,

d. Penetapan dan penjagaan barang yang disita, berlangsung selama proses pemeriksaan, sampai ada putusan pengadilan yang berkekuatan hukum tetap, yang menyatakan sah atau tidak tindakan penyitaan tersebut. ${ }^{10}$

Penyitaan ini merupakan tindakan persiapan untuk menjamin dapat dilaksanakannya putusan perdata. Barang-barang yang disita untuk kepentingan kreditur (penggugat) dibekukan, ini berarti bahwa barang-barang itu disimpan (disconserveer) untuk jaminan dan tidak boleh dialihkan atau dijual (Pasal 197 ayat (9), 199 HIR, 212, $214 \mathrm{Rbg}$ ), maka dari itu penyitaan ini disebut juga sita jaminan. ${ }^{11}$

\section{Teori Conservatoir Beslag (Sita Jaminan)}

Pengertian conservatoir beslag atau sita jaminan ditinjau dari segi yuridis, dimaksudkan mencoba memahami makna sita jaminan sesuai dengan ketentuan undang-undang. Perundang-undangan ketentuan sita jaminan diatur dalam Pasal 227 jo

${ }^{10}$ M. Yahya Harahap, Hukum Acara Perdata, Sinar Grafika, Jakarta, 2005, hlm. 282.

Cit.,hlm. 83
Pasal 197 HIR, atau Pasal 261 jo Pasal 206 Rbg. Ketentuan Pasal 227 HIR atau Pasal $261 \mathrm{Rbg}$, mencoba diambil makna yang terkandung dalam lembaga sita jaminan seperti yang akan diuraikan dibawah ini :

a. Sita sebagai tindakan hukum eksepsional

Sita jaminan merupakan tindakan hukum yang diambil pengadilan mendahului pemeriksaan pokok perkara atau mendahului putusan. Sita jaminan adakalanya telah diletakkan atas harta sengketa atau harta tergugat, sebelum pengadilan memeriksa pokok perkara. Sering juga sita itu dilakukan pada saat proses pemeriksaan perkara sedang berjalan, sebelum hakim menjatuhkan putusan. Tegasnya, sebelum pengadilan menyatakan pihak tergugat bersalah berdasar putusan, tergugat sudah dijatuhi hukuman berupa penyitaan harta sengketa atau harta kekayaan tergugat. Itu sebabnya, tindakan penyitaan merupakan tindakan hukum yang eksepsional. Pengabulan sita jaminan (conservatoir beslag), merupakan tindakan hukum pengecualian, yang penerapannya mesti dilakukan pengadilan dengan segala pertimbangan yang hati-hati sekali, tidak boleh diterapkan secara serampangan tanpa alasan yang kuat dan tidak didukung oleh fakta yang mendasar.

b. Sita sebagai tindakan perampasan Hakekatnya sita jaminan merupakan perintah perampasan atas harta sengketa atau harta kekayaan tergugat. Perintah perampasan itu, dikeluarkan pengadilan dalam surat penetapan 
berdasar permohonan tergugat.

\section{Teori Putusan Hakim}

Hakim setelah mengetahui duduk perkara yang sebenarnya, maka pemeriksaan terhadap perkara dinyatakan selesai, kemudian dijatuhkan putusan. Putusan pengadilan merupakan sesuatu yang sangat diinginkan oleh pihak-pihak yang berperkara untuk menyelesaikan perkara mereka dengan sebaikbaiknya. Pihak-pihak yang berperkara dengan putusan pengadilan tersebut, mengharapkan adanya kepastian hukum dan keadilan dalam perkara yang mereka hadapi. Tujuan suatu proses di muka pengadilan adalah untuk memperoleh putusan hakim yang berkekuatan hukum tetap, artinya suatu putusan hakim yang tidak dapat diubah lagi. Hubungan antara kedua pihak yang berperkara dengan adanya putusan ini, ditetapkan untuk selama-lamanya dengan maksud supaya apabila tidak ditaati secara sukarela maka dipaksakan dengan bantuan alat-alat negara. ${ }^{12}$

\section{E. Metodelogi Penelitian}

Suatu penelitian hakikatnya untuk mendapatkan kebenaran atas sesuatu. Dalam dunia ilmu pengetahuan suatu penelitian tidak akan mencapai hasil yang diharapkan bila tidak ditunjang dengan metode yang tepat dan benar. Adapun Metode penelitian yang digunakan dalam penelitian ini sebagai berikut :

\section{Spesifikasi Penelitian}

Spesifikasi yang digunakan

12 R. Subekti, Hukum Acara Perdata, Bandung, Penerbit Bina Cipta, 1989, hal. 124. adalah penelitian deskriptif analitis yaitu dengan menggambarkan secara jelas obyek yang menjadi permasalahan. Obyek penelitian ini adalah Putusan Pengadilan Negeri Majalengka Nomor 2/Pdt.G/2018/PN Mjl.

\section{Metode Pendekatan}

Metode penelitian ini menggunakan metode pendekatan hukum secara yuridis normatif yaitu pendekatan dengan konsep legis positivistis di mana konsep ini memandang hukum identik dengan norma-norma tertulis yang dibuat oleh lembaga atau pejabat negara yang berwenang, selain itu konsep ini juga melihat hukum sebagai sistem normatif yang mandiri, bersifat tertutup dan terlepas dari kehidupan nyata di mana hukum dikonstruksikan sebagai pencerminan dari kehidupan masyarakat itu sendiri. ${ }^{13}$ Dalam Putusan Pengadilan Negeri Majalengka Nomor 2/Pdt.G/2018/PN $\mathrm{Mjl}$ merupakan hukum yang akan dianalisis dengan norma-norma dan teori-teori hukum, terlepas dari faktor sosial.

\section{Tahap Penelitian}

Sumber data dari penelitian ini adalah data sekunder yang berupa peraturan perundang-undangan, dokumen resmi, dan buku-buku literatur yang berhubungan dengan obyek penelitian. Dari data sekunder tersebut akan dibagi dan diuraikan ke dalam 2 (dua) bagian yaitu :

a. Bahan Hukum Primer, yaitu bahan-bahan hukum yang bersifat mengikat, terdiri dari :

13 Ronny Hanitijo Soemitro, Metodologi Penelitian Hukum dan Jurumetri, Ghalia Indonesia, Jakarta, 1998, hlm. 11-14. 
1).Putusan

Nomor 2/Pdt.G/2018/PN Mj1

2).Herzeine Inlandsch Reglement (HIR)

3). Rechtsreglement

Buitengewesten (RBg)

4). Undang-Undang No 48 Tahun 2009 tentang Kekuasaan Kehakiman

5). Kitab Undang-Undang Hukum Perdata/Burgerlijk Wetboek (BW)

b. Bahan Hukum Sekunder, yaitu bahan-bahan hukum yang memberikan penjelasan terhadap bahan hukum primer, meliputi hasil-hasil penelitian, hasil karya dari kalangan hukum, buku-buku literatur, karya ilmiah dari para sarjana, artikel ilmiah baik dari koran ataupun internet dan dokumen resmi yang berkaitan dengan pokok permasalahan yang diteliti.

\section{Teknik Pengumpulan Data}

a. Data primer, yaitu data yang diperoleh secara langsung dari lapangan guna menunjang data sekunder, sehingga dari data primer akan dapat diketahui bagaimana pelaksanaan terhadap Putusan Nomor 2/Pdt.G/2018/PN Mj1.

b. Data Sekunder diperoleh dengan melakukan inventarisir terhadap putusan pengadilan, peraturan perundang-undangan, asas hukum, yurisprudensi, buku-buku literatur, karya ilmiah sarjana dan dokumendokumen yang berhubungan dengan permasalahan yang diteliti, untuk selanjutnya dipelajari sebagai satu kesatuan yang utuh.

\section{Analisis Data}

Data yang diperoleh selanjutnya akan dianalisis dengan menggunakan metode normatif kualitatif yaitu dengan menjabarkan data yang telah diperoleh berdasarkan norma-norma hukum atau kaidah yang relevan dengan pokok permasalahan.

\section{Lokasi Penelitian}

Penelitian ini akan dilaksanakan di Pengadilan Negeri Majalengka yang beralamat di Jl. K.H Abdul Halim No. 499, Kecamatan Cigasong, Kabupaten Majalengka.

\section{F. Pembahasan Fungsi dan kedudukan sita jaminan dalam perkara perdata}

\section{Fungsi Dan Kedudukan Daripada Sita Jaminan Dalam Perkara Perdata}

Tujuan sita jaminan utamanya adalah agar tergugat tidak memindahkan atau membebankan harta kekayaan kepada pihak ketiga, inilah yang menjadi salah satu tujuan sita jaminan yaitu untuk menjaga keutuhan keberadaan harta kekayaan tergugat selama proses pemeriksaan perkara berlangsung sampai perkara memperoleh putusan yang berkekuatan hukum tetap.

Agar terdapat suatu barang tertentu yang nantinya dapat dieksekusi sebagai pelunasan utang tergugat, sita conservatoir merupakan sita jaminan tehadap barang milik debitur atau tergugat. Sita conservatoir merupakan tindakan persiapan dari pihak penggugat dalam bentuk permohonan kepada 
pengadilan, yaitu berupa penjaminan agar dilaksanakannya putusan perdata dengan cara membekukan barang milik tergugat. Barang yang dibekukan tersebut nantinya dapat digunakan untuk melaksanakan putusan pengadilan.

Contoh : Dengan menjual barang yang disita dan uangnya digunakan untuk membayar kewajiban tergugat kepada penggugat sesuai putusan hakim. Terhadap sita conservatoir, tergugat juga dapat mengajukan permohonan kepada hakim agar sita atas barangnya tersebut dicabut. Permohonan pencabutan itu dapat dikabulkan oleh hakim asalkan tergugat dapat menyediakan tanggungan yang mencukupi.

Barang bergerak yang disita harus dibiarkan tetap berada di tangan tergugat untuk disimpannya dan dijaganya, atau dapat juga disimpan di tempat lain, dan tergugat dilarang mengalihkan barang tersebut. Dengan adanya sita conservatoir, tergugat sebagai "pemilik barang" kehilangan kewenangannya atas barang miliknya itu. Selain terhadap barang bergerak, sita conservatoir juga dapat diajukan atas barang tidak bergerak milik tergugat. Penyitaan atas barang tidak bergerak milik tergugat dilakukan dengan mengumumkan penyitaan barang tidak bergerak tersebut oleh kepala desa setempat di tempat barang itu disita. Sita conservatoir, juga dapat dilakukan terhadap barang bergerak milik tergugat yang berada di tangan pihak ketiga. Hal ini misalnya terjadi karena tergugat memiliki piutang terhadap seorang pihak ketiga. Untuk menjamin haknya atas pelaksanaan putusan, penggugat dapat melakukan sita conservatoir atas barang bergerak milik debitur yang di tangan pihak ketiga itu. Sita conservatoir atas barang bergerak milik tergugat yang berada di tangan pihak ketiga disebut juga derdenbeslag.

Mengingat bahwa penyitaan merupakan tindakan yang eksepsional, oleh karena itu dibalik hal tersebut pasti memiliki tujuan tertentu, sehingga pada akhirnya pun dapat dilakukan tindakan yang eksepsional. Adapun tujuan dari penyitaan itu sendiri diantaranya adalah sebagai berikut:

a. Menjaga barang yang disengketakan

Tujuan utama penyitaan adalah agar barang harta kekayaan Tergugat tidak dipindahkan kepada orang lain melalui jual-beli atau penghibahan dan sebagainya, dan juga agar tidak dibebani dengan sewa- menyewa atau diagunkan kepada pihak ketiga. Maksudnya disini untuk menjaga keutuhan dan keberadaan harta kekayaan Tergugat tetap utuh seperti semula, selama proses penyelesaian perkara berlangsung agar pada saat putusan memperoleh kekuatan hukum yang tetap, barang yang disengketakan dapat diserahkan dengan sempurna kepada Penggugat. ${ }^{14}$

b. Agar gugatan tidak hampa

Selain untuk menjaga keutuhan barang, salah satu tujuan dari sita jaminan adalah agar gugatan Penggugat tidak illusoir atau tidak hampa pada saat putusan dilaksanakan. Maksudnya disini

14 Wildan Suyuthi, Sita dan Eksekusi:Praktek Kejurusitaan Pengadilan, Jakarta, PT Tatanusa, 2004, hlm. 20 
adalah apabila perkara yang disengketakan mengenai tuntutan pembayaran sejumlah uang, harta yang disita tetap utuh sampai putusan berkekuatan hukum tetap sehingga apabila Tergugat tidak melaksanakan pemenuhan pembayaran secara sukarela, pemenuhan dapat diambil dari barang harta kekayaan Tergugat dengan jalan menjual lelang barang yang disita tersebut. ${ }^{15}$

c. Objek Eksekusi Sudah Pasti

Pada saat permohonan sita diajukan, Penggugat harus menjelaskan dan menujukkan identitas barang yang hendak disita. Menjelaskan letak, jenis, ukuran dan batas-batasnya. Atas permohonan itu, pengadilan melalui juru sita memeriksa dan meneliti kebenaran identitas barang pada saat penyitaan dilakukan. Bertitik tolak dari permohonan dan pelaksanaan sita, sejak semula sudah diketahui dan pasti objek barang yang disita. Lebih lanjut, hal ini langsung memberi kepastian atas objek eksekusi, apabila putusan telah berkekuatan hukum tetap. ${ }^{16}$

Kepastian objek eksekusi atas barang sitaan semakin sempurna sesuai dengan penegasan Mahkamah Agung yang menyatakan kalau putusan telah berkekuatan hukum tetap maka barang yang disita, demi hukum langsung menjadi sita eksekusi. ${ }^{17}$

${ }^{15}$ M. Yahya Harahap, Op.Cit.,hlm.285 ${ }^{16} \mathrm{Ibid}$.

17 Mahkamah Agung Republik Indonesia (b) Himpunan Tanya Jawab Rakerda MARI 1987-1993, Jakrta, 1997, hlm 177
2. Pertimbangan Hukum Dari Hakim Pengadilan Negeri Majalengka Dalam Mengkualifisir Permohonan Sita Jaminan, Sehingga Menyatakan Sah Dan Berharga Dalam Putusan 2/Pdt.G/2018/PN.Mjl

Conservatoir beslag atau sita jaminan ditinjau dari segi yuridis, dimaksudkan mencoba memahami makna sita jaminan sesuai dengan ketentuan undang-undang. Sita jaminan merupakan tindakan hukum yang diambil pengadilan mendahului pemeriksaan pokok perkara atau mendahului putusan. Sita jaminan adakalanya telah diletakkan atas harta sengketa atau harta tergugat, sebelum pengadilan memeriksa pokok perkara. Sita jaminan sering juga dilakukan pada saat proses pemeriksaan perkara sedang berjalan, sebelum hakim menjatuhkan putusan. Tegasnya, sebelum pengadilan menyatakan pihak tergugat bersalah berdasar putusan,

tergugat sudah dijatuhi hukuman berupa penyitaan harta sengketa atau harta kekayaan tergugat, itulah sebabnya tindakan penyitaan merupakan tindakan hukum yang eksepsional. Pengabulan sita jaminan (conservatoir beslag), merupakan tindakan hukum pengecualian, yang penerapannya

seharusnya dilakukan pengadilan dengan segala pertimbangan yang hati-hati sekali. Pengabulan sita jaminan (conservatoir beslag) tidak boleh diterapkan secara tidak bijaksana tanpa alasan yang kuat, yang tidak didukung oleh fakta yang mendasar.

Pengajuan conservatoir beslag pada praktek peradilan yang sesuai 
dengan ketentuan undang-undang memiliki dua cara, yaitu :

a. Permohonan diajukan dalam surat gugatan.

Bentuk tata cara pengajuan permohonan conservatoir beslag yang seperti ini yang sering dijumpai dalam praktek. Penggugat mengajukan permohonan conservatoir beslag secara tertulis dalam surat gugatan, sekaligus mengajukan dengan pengajuan gugatan pokok kepada Ketua Pengadilan Negeri. Dalam bentuk ini keduanya bersatu antara gugatan pokok dengan permohonan conservatoir beslag dan tidak terpisah.

b. Permohonan conservatoir beslag diajukan secara terpisah dari surat gugatan.

Bentuk pengajuan permohonan conservatoir beslag yang kedua ini, diajukan penggugat dalam permohonan tersendiri, terpisah dari gugatan dan dilakukan setelah pemeriksaan perkara berjalan maka dalam permohonan harus diajukan kepada Ketua Majelis Hakim pemeriksa perkara.

Pengajuan conservatoir beslag menurut ketentuan undang-undang, waktu pengajuannya dapat dilakukan

a. Selama putusan belum dijatuhkan atau selama putusan belum berkekuatan hukum tetap.

b. Sejak mulai berlangsung pemeriksaan perkara di sidang pengadilan negeri sampai putusan dijatuhkan.

c. Atau selama putusan belum dieksekusi.

Berdasarkan hasil penelitian pada posita/fundamentum petendi Nomor 34 dan pada petitum/tuntutan penggugat Nomor 6 . Permohonan conservatoir beslag apabila dikaitkan dengan ketentuan yang mengatur tentang cara dan tenggang waktu pengajuan conservatoir beslag sudah benar. Permohonan conservatoir beslag diajukan dalam surat gugatan sebelum putusan dijatuhkan. Pengajuan permohonan conservatoir beslag oleh pihak yang berkepentingan harus bedasarkan alasan-alasan yang dibenarkan oleh undang-undang, yaitu alasan-alasan menurut Pasal 227 HIR, antara lain :

a. Ada persangkaan yang beralasan.

b. Tergugat akan menggelapkan barang-barangnya.

c. Dengan maksud menjauhkan barang-barang itu dari kepentingan penggugat.

d. Sebelum putusan berkekuatan hukum yang tetap.

Semua unsur-unsur alasan itu merupakan satu kesatuan yang tak terpisah antara yang satu dengan yang lain.

Ada persangkaan yang beralasan dan Tergugat akan menggelapkan barang-barangnya.

Hakim yang berhak dan berwenang menentukan penilaian persangkaan, bukan Penggugat. Penggugat berhak mengajukan fakta- 
fakta tentang adanya dugaan atau persangkaan berupa petunjukpetunjuk penggelapan yang hendak dilakukan Tergugat atas harta terperkara atau harta kekayaannya, penilaiannya tergantung pada pendapat dan pertimbangan hukum. Hakim jangan mudah terpengaruh atas fakta dan petunjuk yang dikemukakan Penggugat, sebelum menemukan fakta dan petunjuk yang kuat. Sikap dan pendekatan penerapan penilaian persangkaan yang tepat sebagai unsur alasan pengabulan sita jaminan, sedapat mungkin lebih mengarah kepada pendekatan penilaian yang bersifat materil. Sikap dan pendekatan yang mengarah kepada penilaian materiillah yang wajar mensejajari pembenaran sifat eksepsional sita jaminan. ${ }^{18}$

Menurut Yahya Harahap ada tiga batasan minimal yang dianggap bernilai untuk mensahkan alasan persangkaan, apabila ketiga batasan tersebut dihubungkan dengan perkara nomor 2/Pdt.G/2018/PN.Mjl maka dapat ditemukan fakta-fakta sebagai berikut :

a. Ada fakta yang mendukung persangkaan.

Dari posita/fundamentum petendi nomor 2 bahwa total simpanan/tabungan nasabah koperasi Dwi Fani sebesar Rp. 2.391.494.600,- (Dua milyar tiga ratus Sembilan puluh satu juta empat ratus Sembilan puluh empat

18 M. Yahya Harahap, Permasalahan dan Penerapan Sita Jaminan Conservatoir Beslag, Bandung, Pustaka, 1990, hlm. 35-36. ribu enam ratus rupiah) sampai saat gugatan ini diajukan di bulan januari tahun 2018 belum pernah dikembalikan oleh pihak koperasi sehingga para nasabah koperasi merasa dirugikan oleh koperasi Dwi Fani.

b. Ada petunjuk yang membenarkan persangkaan.

Dari posita/fundamentum petendi Nomor 3 bahwa para penggugat yang paling utama merasa khawatir karena pimpinan koperasi yakni Tergugat I telah dijatuhi hukuman pidana melakukan penggelapan di Pengadilan Negeri Majalengka pada tanggal 22 Mei 2017 nomor perkara 29/Pid.B/2017/PN Mjl, maka oleh sebab itu para penggugat mengajukan gugatan perbuatan melawan hukum terhadap koperasi Dwi Fani akibat tidak keluarnya uang simpanan para nasabah koperasi sampai tahun 2018, tentunya sudah merugikan para nasabahnya.

c. Fakta atau petunjuk itu harus masuk akal. ${ }^{19}$

Batas minimal atau persangkaan, bertujuan untuk membatasi kewenangan hakim secara yuridis atau pengabulan onservatoir beslag. Persangkaan yang harus diwujudkan dan diketemukan hakim ditinjau dari segi yuridis adalah persangkaan yng benarbenar didukung oleh fakta atau petunjuk-petunjuk agar alasan pengabulan conservatoir beslag tidak didasarkan pada penilaian subjektif. Hakim membebankan

${ }^{19}$ Ibid, hlm. 36. 
kepada

penggugat

untukmendapatkan

fakta dan

petunjuk-petunjuk,. Penggugat

wajib mengajukan fakta dan

petunjuk-petunjuk tentang adanya

persangkaan itu.

Penggugat atau pemohon conservatoir beslag atau sitajaminan yang tidak mampu mengajukan fakta atau petunjukpetunjuk tentang adanya kehendak dan maksud tergugat untuk menggelapkan harta terperkara atau harta kekayaannya, berarti belum memenuhi alasan. Hakim harus tegas untuk menolak permohonan sita yang belum memenuhi syarat alasan yang sah.

Para tergugat secara tidak sah dan melawan hukum telah lalai dalam mengelola simpanan/tabungan nasabah koperasi Dwi Fani sebesar Rp. 2.391.494.600,- (Dua milyar tiga ratus Sembilan puluh satu juta empat ratus Sembilan puluh empat ribu enam ratus rupiah) sampai saat gugatan ini diajukan di bulan januari tahun 2018 belum pernah dikembalikan oleh pihak koperasi sehingga para nasabah koperasi merasa dirugikan oleh koperasi Dwi Fani sehingga cukup alasan untuk mengabulkannya.

Dengan maksud menjauhkan barang-barang itu dari kepentingan penggugat Posita/fundamentum petendi Nomor 3 dapat dijelaskan bahwa perbuatan para Tergugat merupakan perbuatan melawan hukum yaitu koperasi Dwi Fani tidak bias mengembalikan uang simpanan para nasabah koperasi sebesar Rp. 2.391.494.600,- (Dua milyar tiga ratus Sembilan puluh satu juta empat ratus Sembilan puluh empat ribu enam ratus rupiah) sampai saat gugatan ini diajukan di bulan januari tahun 2018, tentunya sudah merugikan para nasabahnya.. Pertimbangan hukum dalam hal ini telah ditetapkan sebagai fakta hukum yang merupakan bagian dari perbuatan melawan hukum yang telah terbukti dilakukan oleh para Tergugat. Sebelum putusan berkekuatan hukum yang tetap. Berdasarkan hasil penelitian pada pertimbangan pokok perkara, penetapan sita jaminan atau conservatoir beslag terhadap tanah dan bangunan sengketa tersebut sudah benar. Penggugat dalam mengajukan permohonan conservatoir beslag memiliki alasan yaitu adanya kekhawatiran dan adanya dugaan cukupberalasan menurut hukum bahwa tergugat secara tidak sah dan melawan hukum telah melakukan proses pencairan pinjaman fiktif yang dilakukan oleh tergugat I dilakukan secara bersama dan atau sama tau antara tergugat II, tergugat III, dan tergugat $\mathrm{V}$ yang akibatnya uang simpanan para nasabah tidak bias dikembalikan, tentunya hal tersebut secara tanggung renteng tergugat I, tergugat II, tergugat II, tergugat IV dan tergugat $\mathrm{V}$ bertanggungjawab atas seluruh uang milik nasabah yang 
tidak kembali dan secara tanggung renteng wajib mengembalikan uang simpanan milik penggugat sebesar Rp. 2.391.494.600,- (Dua milyar tiga ratus Sembilan puluh satu juta empat ratus Sembilan puluh empat ribu enam ratus rupiah) .

Pengumuman berita acara sita termasuk salah satu syarat formal yang akan mendukung keputusan dan kekuatan mengikatsita jaminan yang telah dilaksanakan. Syarat ini jika tidakdipenuhi, yuridis formil sita jaminan belum sah, sehingga tidakmempunyai kekuatan hukum mengikat kepada pihak tergugat. Pengumuman berita acara penyitaan yang diatur dalam Pasal 198HIR dan Pasal 213 RBg, bertujuan untuk memberitahukan kepada khalayak ramai tentang telah diletakkannya penyitaan pada barangharta kekayaan tergugat, agar masyarakat mengetahui tentangstatus barang yang bersangkutan sedang berada dalam keadaantersita. ${ }^{20}$ Pengumuman berita acara yang dianggap undangundangmemenuhi syarat formil, harus menurut cara-cara yang ditentukanundang-undang yaitu harus dicatat dalam buku kamus pendaftarandan juru sita harus memerintahkan kepala desa memperhatikansita. Obyek tanah yang disita jikalau belum bersertifikat,pendaftaran berita acaranya dicantumkan dalam buku letter C dikantor Kepala Desa.

${ }^{20}$ M. Yahya Harahap, op.cit, hlm. 81.
Syarat formil pengumuman berita acara sita yaitu melaluiinstansi kantor pendaftaran dan kepala desa, masih diperlukansyarat formil pernyataan sah dan berharga oleh hakim majelis yangmemerintahkan penyitaan. Syarat formil yang dimaksud diaturdalam Pasal 226 ayat 7 HIR atau Pasal 261 ayat $6 \mathrm{RBg}$. Syarat formil ini lazim disebut pernyataan berharga atau van waardeverklaard, yang bertujuan untuk mensahkan dan menyatakan berharga sita jaminan (conservatoir beslag) yang dilakukan oleh juru sita. Pengumuman atau pernyataan sah dan berharga sita jaminan, dilakukan hakim ketua majelis di persidangan yang dihadiri oleh kedua belah pihak yang berperkara. Hakim ketua majelis mengumumnkan di persidangan tentang sah dan berharga sita jaminan yang dilaksanakan juru sita terhadap harta terperkara atau harta kekayaan tergugat, sebagaimana yang tertera dalam berita acara sita jaminan dengan menyebut tanggal, bulan dan tahun, serta nomor berita acara yang dimaksud. Pengumuman pernyataan sah dan berharga, dilakukan hakim ketua majelis pada sidang berikutnya jika pengabulan dan perintah serta pelaksanaan penyitaan dilakukan pada saat proses pemeriksaan pokok perkara sedang berlangsung. Pengabulan permohonan penyitaan seandainya baru dikabulkan dan diperintahkan pada berharga harus dilakukan hakim ketua majelis pada siding berikutnya (sidang yang 
ketujuh). ${ }^{21}$ Pengumuman di persidangan saja belum sempurna memenuhi persyaratan.

Persyaratan pengumuman di persidangan supaya benar-benar sah dan berharga, diperlukan persyaratan lanjutan sebagai syarat formil. Persyaratan lanjutan tersebut berupa penegasan dalam amar putusan. Sita jaminan yang telah diumumkan sah dan berharga di persidangan,dinyatakan lagi secara tegas dalam amar putusan pokok perkarayang rumusan bukunya berbunyi : menyatakan sah dan berharga sita jaminan (conservatoir beslag). ${ }^{22}$

Berdasarkan hasil penelitian pada pertimbangan hukum,hakim ketua majelis menyatakan sah dan berharga sita jaminan dengan menyebutkan tanggal, bulan, tahun, serta nomor beritaacara yaitu Berita Acara Penyitaan Nomor 2/Pen.Pdt.G/2018/PN.Mjl tanggal 5 Juni 2018. Amar putusan berdasarkan hasil penelitian, menyatakan sah dan berharga terhadap sita jaminan (conservatoir beslag) telah dinyatakan secara tegas oleh hakim ketua majelis dalam amar putusan, sehingga pernyataan sah dan berharga sita jaminan di persidangan sudah sempurna memenuhi persyaratan formil. Perkara nomor : 2/Pdt.G/2018/PN.Mj1 setelah persyaratan formil sah dan berharganya sita jaminan

${ }^{21}$ Ibid, hlm. 83.

${ }^{22}$ Ibid, hlm. 84 (conservatoir beslag) terpenuhi, maka sesuai dengan hasil penelitian pada petitum/tuntutan penggugat nomor 6 dan amar putusan, sita jaminan (conservatoir beslag) terhadap tanah dan bangunan yang merupakan objek sita jaminan dapat dilaksanakan dengan sendirinya. Tergugat harus memenuhi tuntutan dari para penggugat yaitu menyerahkan 12 (dua belas) bidang tanah dan bangunan objek sengketa tersebut kepada para penggugat sebagai ganti uang milik para penggugat dan nasabah koperasi Dwi Fani sebesar Rp. 2.391.494.600,(Dua milyar tiga ratus Sembilan puluh satu juta empat ratus Sembilan puluh empat ribu enam ratus rupiah).

\section{G. Kesimpulan}

Berdasarkan perumusan masalah yang penulis kemukakan serta pembahasannya, maka penulis menyimpulkan beberapa hal sebagai berikut :

1. Bahwa Conservatoir Beslag (sita jaminan) adalah suatu tindakan persiapan untuk menjamin dapat dilaksanakannya putusan perdata. Pelaksanaan Conservatoir Beslag diatur dalam Pasal 197 HIR, j o 227 HIR dan pasal 261 jo pasal 206 RBG. Pelaksanaan Conservatoir Beslag diawali dengan adanya penetapan Conservatoir Beslag dari Majelis Hakim Pengadilan Negeri dan surat perintah kepada panitera atau juru sita Pengadilan Negeri untuk 
melakukan penyitaan terhadap obyek sengketa. Panitera maupun juru sita dibantu oleh dua orang saksi yang telah dewasa Pasal 197. Tahap terakhir dalam pelaksanaan sita jaminan adalah pembuatan berita acara sita jaminan sesuai dengan ketentuan Pasal 197 HIR, tanpa adanya berita acara sita jaminan, penyitaan tersebut dianggap tidak sah.

2. Koperasi Dwi Fani dinyatakan telah melakuan perbuatan melawan hukum, sehingga Tergugat I sebagai Ketua, Tergugat II sebagai sekertaris, Tergugat III dan Tergugat IV sebagai bendahara dan Tergugat V sebagai pengawas dari Koperasi Dwi Fani yang sah dan bertanggung jawab secara tanggung renteng untuk membayar uang milik Para penggugat sebagai nasabah koperasi Dwi Fani sebesar Rp.2.391.494.600 (dua miliar tiga ratus sembilan puluh satu juta empat ratus sembilan puluh empat ribu enam ratus Rupiah) secara kontan. Dan dalam putusannya dinyatakan sah dan berharga sita jaminan yang telah dilaksanakan oleh Jurusita/ Jurusita Pengganti Pengadilan Negeri Majalengka Kelas II berdasarkan Berita Acara Penyitaan Nomor 2/Pen.Pdt.G/2018/PN. Mjl tanggal 5 Juni 2018.

\section{H. Saran}

Kewenangan yang mutlak yang dimiliki oleh hakim dalam pengabulan Sita Jaminan (conservatoir beslag) hendaknya dilakukan dengan penuh kehati-hatian berdasarkan pendekatan penerapan penilaian alasan yang tepat sebagai unsur alasan pengabulan Sita Jaminan (conservatoir beslag), agar kekeliruan dalam pengabulan Sita Jaminan (conservatoir beslag) dapat dihindari.

\section{DAFTAR PUSTAKA}

Buku :

Abdulkadir Muhammad, Hukum Perikatan, Citra Aditya Bhakti, Bandung, 1990

Burhanuddin Susamto, , Koperasi Syariah dan Pengaturannya di Indonesia,

Hendrojogi. Koperasi: Asas-asas, Teori dan Praktik. Edisi 4. Jakarta. Raja Grafindo Persada.
2007

M. Yahya Harahap, Hukum Acara Perdata, Sinar Grafika, Jakarta, 2005

dan Penerapan Sita Jaminan Conservatoir Beslag, Bandung, Pustaka, 1990

R. Subekti, Hukum Acara Perdata, Bandung, Penerbit Bina Cipta, 
1989

Retnowulan Sutantio dan Iskandar

Oeripkartawinata, Hukum

Acara Perdata Dalam

TeoridanPraktek, Mandar

Maju, Bandung, 2002

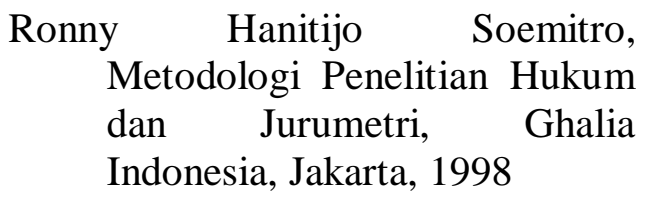

Ropaun Rambe, Hukum Acara

Perdata Lengkap, Sinar

Grafika, Jakarta, 2002

Sudikno Mertokusumo, Hukum Acara Perdata Indonesia, Liberty, Yogyakarta, 2006
Wildan Suyuthi, Sita dan Eksekusi:Praktek Kejurusitaan Pengadilan, Jakarta, PT Tatanusa, 2004

\section{Sumber Lain :}

Mahkamah Agung Republik Indonesia (b) Himpunan Tanya Jawab Rakerda MARI 1987-1993, Jakrta, 1997

Wikipedia, Negara Hukum, https://id.wikipedia.org/w iki/Negara__ hukum, diakses Bulan Nopember 2018 